\title{
The Social Development among Preschool Children: Analysis of Sociodramatic Play
}

\author{
Firmaniah Zulkarnaini \\ PAUD Islam Nibras, Perguruan Islam Nibras, Padang, Sumatera Barat, Indonesia
}

Corresponding e-mail: $\underline{\text { m_firmaniah@yahoo.com }}$

\begin{abstract}
The aim of this study is to identify a popular child, an unpopular child and the reasons an unpopular child is in sociodramatic play. The methods used are observation and sociometrist technique. It was conducted on 25 preschool children, which was five to six years. Sociometrist technique involved the selection of the peers preferred through the interview, tabulation table and make a sociogram. The data analysis was performed by using descriptive analysis in the frequency and percent. The results showed that the highest frequency of a popular child is eleven times and the lowest frequency of an unpopular child with rejection categories is one times. Further the absence frequency of an unpopular child with rejected categories. The results also showed that girls are more popular than boys. The reason an unpopular child in sociodramatic play showed that personality traits as the biggest factor namely they like crying, sulking, cowardly and shy. Therefore, preschool teachers need to take certain steps to help and give opportunities to children who suffer from social development when interacting with peers. The implications of the study suggest peer interaction should be taken into account in the further education.
\end{abstract}

Keywords: Social development, sociodramatic play, preschool children

\section{INTRODUCTION}

Sociodramatic play is one of the centers of learning in preschool education. According to Piaget (1972), sociodramatic playing is a form of pretend play that involves a lot of group interaction in which each of its members play different roles within their group. Sociodramatic play this can be regarded as a continuation to symbolic play or pretend play. Next, according to Piaget, pretend play involves interaction with friends as a player which eventually transformed and made sociodramatic play.

Many previous studies showed that sociodramatic playing contribute to the improvement of the children. Lee (2007); Hanline, Milton \& Phelps (2008). Using the sociodramatic play and his role in the cognitive aspects. Godwin \& Ashiabi (2007) analyzed relationship the emotional and social aspects. Deunk (2008) studied of the characteristics of sociodramatic play. Bluiett (2009) studied sociodramatic play in terms of language. Meanwhile Boyle \& Charles (2010) analyzing about instructions related to literacy.

Barker \& Wright (1955) express that children 2 years old spends $10 \%$ of his daylight time to interact with peers. At the age of 4 years, time spent interacting with peers increased to $20 \%$. While children aged 7 to 11 years old spend more than 40 $\%$ to interact with peers. Essentially, children need to build relationships with peers to enable social development. Social development is defined as the ability to interact with others (Yusuf, 2007).

The development of children's social interactions with peers consists of two categories: popular children and unpopular children. The popular children is many friends or prefer friends. Children unpopular distinguished from rejected children and neglected children. Children who are neglected means children who receive little attention from their peers, but that does not mean they are not liked 
by his peers. Children who are rejected means children who are not liked by his peers. According Santrock (1995), $10 \%$ to $20 \%$ of children are not preferred as a friend play is children who are shy. According to Coolahan et al. (2000) peer relationships that are not healthy in the early stages of life is associated with many negative consequences on the next stage of development. This view is also consistent with the view Brendgen, Little \& Krappmann (2000) believes that children who have a peer relationship is not good and the refusal by the other partners will have the opportunity to deal with various problems of social adjustment and emotional, failure in learning and then tend to drop outs from school. Therefore, the social development of children at the ages of four to six years through interaction with peers is an important aspect in the development stage (Oden, 1987; Garvey 1990; Hartup 1992).

Based on the findings Coolahan et al. (2000) that social relationships have a positive correlation with achievement motivation which in turn has a strong influence on the success and learning. Ishak (2001), found that through peer evaluation, the child can be categorized as a friend who is very popular, popular and unpopular. Studies Ishak (2010) about the behavior and peer relationships play among preschoolers, found that respondents tend to choose specific friends to play. This is also evidenced by the Bergen (1988) found that children who are involved in the sociodramatic play with high frequency is more popular among their peers.

This study aims to identify children who are popular, unpopular and the reasons for a child unpopular when sociodramatic playing. The objectives of this study were: (1) to identify the popular children during sociodramatic play; (2) to identify children who are unpopular while sociodramatic playing; and (3) to identifying the reasons for an unpopular child while sociodramatic playing.

\section{METHODOLOGY}

This study was conducted through observation and sociometry technique. The total of sample are 25 children of a preschool, 13 males and 12 females, they six years old of a preschool education center in the area were selected for the study.

The Sociometry is a method to obtain data on the pattern and structure of the relationship between individuals in a group (Hallinan 1981; Nurkancana 1993; Kartono 1996). Sociometry technique is carried out in which children are asked to state the five preferred partners while sociodramatic playing through interviews. Based on the responses of children, data compiled in the form of a distribution table. Analysis of the responses of children carried out by determining the frequency of a person favored by a friend of the popular child and an unpopular child. Popular children are when getting the most number of frequencies and unpopular child when getting the lowest frequency. An unpopular child which gets little number of frequencies are category neglected temporary of category rejected when there is no frequency at all. The data were analyzed using sociogram to determine the relationship between children during sociodramatic play. Sociometry technique was adapted from methods used by Moller et al. (1992); Fabes et al. (1997). While the observation method is used to determine the reasons for an unpopular child while sociodramatic playing based on three categories of personality traits, feelings and behavior. Data analysis was done using descriptive analysis in the form of frequency and percentage.

\section{RESULT AND DISCUSSION}

Based on Figure 1, the result indicates the children can be categorized popular children i.e. frequency $=11$, three unpopular children, categories are neglected ie frequency $=1$, and two children categories is rejected, ie frequency $=0$. Popular children are girls (TA), unpopular child category neglected is boys (AM, AF) and girls (SK). Temporary, of category rejected is girls (FT, $\mathrm{SH})$. 


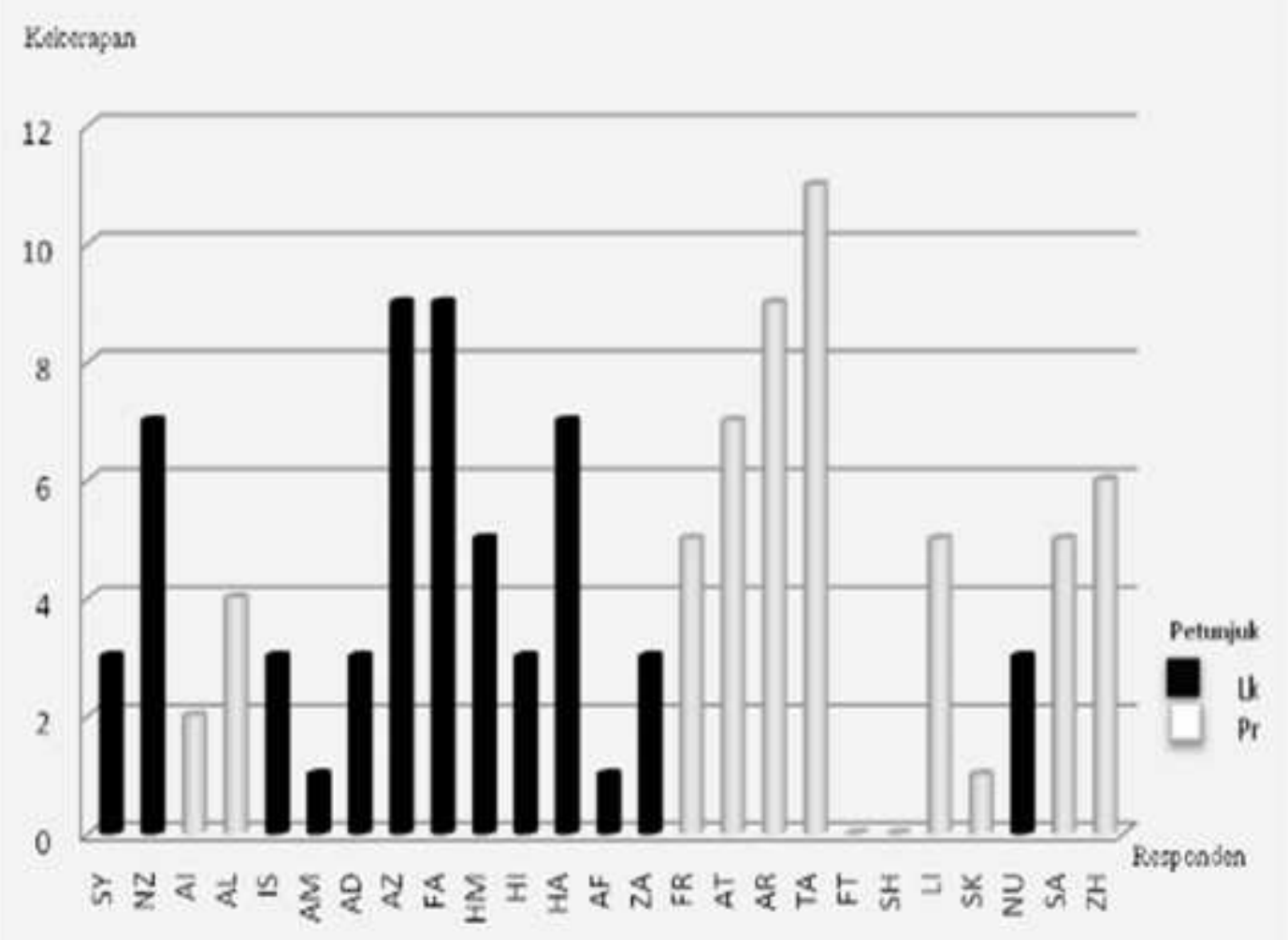

Figure 1. Frequency distribution of respondents: the preferred partner

The findings of the frequency response of children to a friend who liked the sociodramatic play shows also that their selection pattern according to gender. Selection pattern, there are three categories of kids who liked boys as friends sociodramatic playing, children who liked the girls as friends sociodramatic playing and children who liked boys or girls as friend sociodramatic play. Comparison of the overall responses of children to a friend who liked the sociodramatic play based on the frequency and percentage are in Table 1.
Table 1. Distribution of selection patterns based on sex friend

\begin{tabular}{lcc}
\hline \multicolumn{1}{c}{ Category } & Frequency & Percentage \\
\hline children like boys as friends & 9 & $36 \%$ \\
children like girls as friends & 11 & $44 \%$ \\
children like boy and girls & 5 & $20 \%$ \\
as friends & & \\
\hline
\end{tabular}




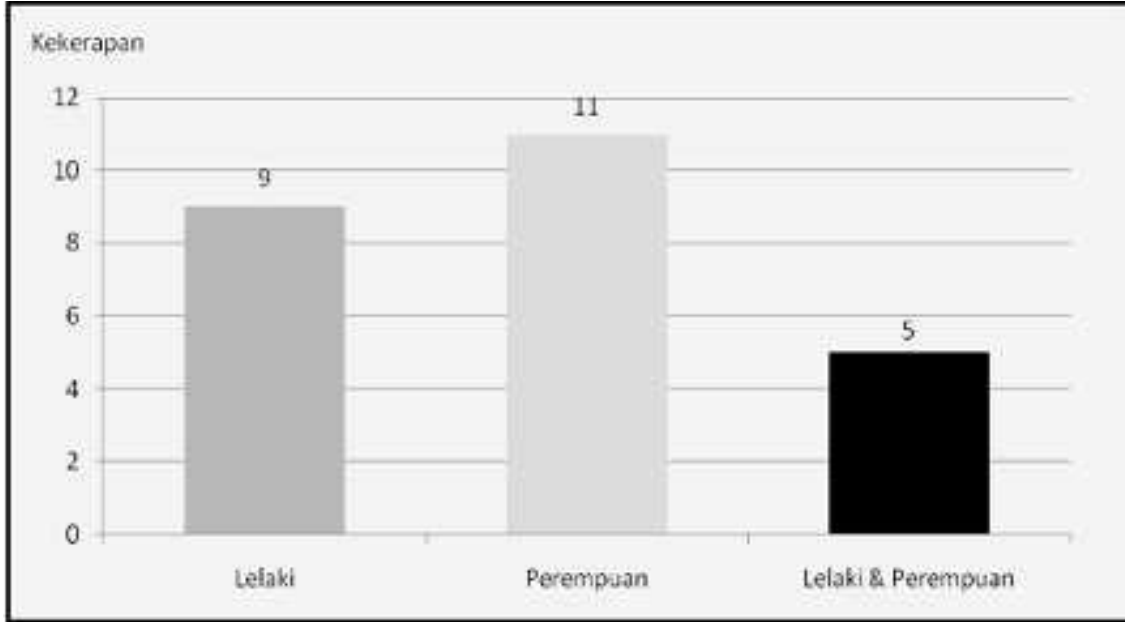

Figure 2. Distribution of the frequency of elections friend with categories like boys, girls, boys and girls

Table 1 and Figure 2 shows the frequency pattern that favored the election of a friend while sociodramatic playing categories like boys as friends sociodramatic playing is $9(36 \%)$, followed by frequency liked girls as friends sociodramatic playing $11(44 \%)$. While the frequency liked boys or girls as friends sociodramatic playing was 5 (20 $\%)$.

Category of children who like boys or girls as friends sociodramatic playing form a pattern represented by sociogram in Figure 3. The results show a total of four boys who liked girls as his playing partner, namely; (1) NZ liked TA, AR, AT as a friend play; (2) ZA liked the TA as a friend play; (3) AM liked AI as a friend play; (4) HA liked the SA as a friend play and one girls liked boys as his playing partner of AT liked AM, HA. However, the pattern does not reflect the mutuality. This means the relationship between a children is not a one-way pattern reciprocity. Decision finding also shows that TA (popular children) and AM (unpopular children) are also included in the category of favored as a friend sociodramatic play not only same gender, but also liked by the opposite sex.

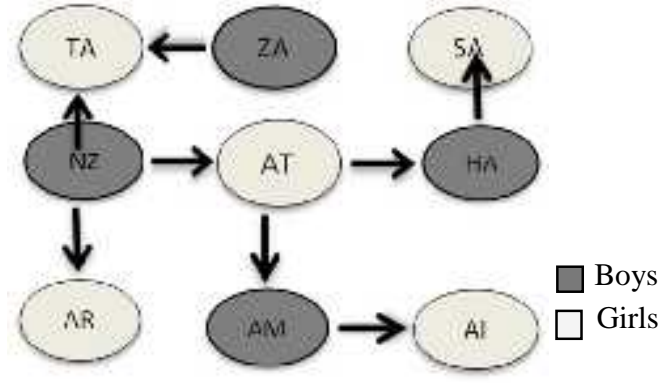

Figure 3. The relationship of respondents

Figure 4 shows an unpopular child due to three factors, personality traits, feelings and behavior. The findings showed that the factor personality traits (84\%) higher than the feelings (12\%) and behavioral factors (4\%). Personality is like crying, sulking, cowardly and shy. The feeling was the speech that might offend, such as "small body", "Even then, do not know", "You shut up". Next in terms of behavior as well as the rugged disruptive game. 


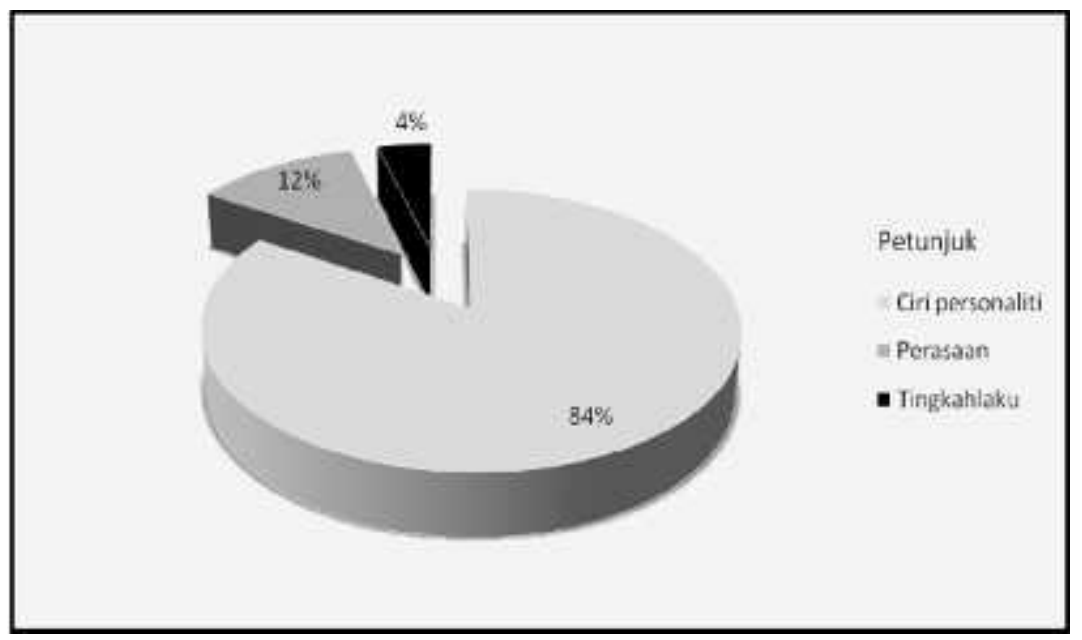

Figure 4. The reason an unpopular child

Sociometry based performed in this study, there is a children's popular and unpopular. Results of the study showed that the children are the popular kids, three children were unpopular categories are neglected and two children were unpopular categories declined. This decision refers to children's responses to the friend who liked the sociodramatic play. Children who are involved in sociodramatic play with high frequency will be popular among peers (Bergen 1988). This finding is most likely due to the tendency of the majority of children liked the friend of the same gender than the friend of the opposite sex (Asher \& Hymel 1981) as well as the differences in development and social adjustment of boys and girls (French 1990; Ladd 1983) .

However, the relationship between the children shows a reciprocal relationship is more dominant than one way. Based on sociogram, children's popular and unpopular children are children who favored same gender and friend of the opposite sex. This is happened because the play involves a lot of interaction sociodramatic group where each member playing a different character. Sociodramatic play foster children's social skills to share, cooperate and comply with the regulations (Smilansky 1979). In addition, the influence of peers influence social development of children, for example language patterns, signal altruistic (behavior in which children are more likely to put the interests of others rather than self-interest or caring for others, especially the weak), popularity among their peers and moral beliefs. The development of social competence from birth and rise rapidly in preschool (McClellan \& Katz 2001).

Personality is the most dominant factor of the feelings and behavioral factors that make the reasons for an unpopular child. This study found that behavioral factors rugged or disruptive game is not the dominant factor that causes an unpopular child while sociodramatic playing. This finding is in contrast to previous studies which stated that the reasons for an unpopular child because the physical act of liked stirring (Salma Ishak, 2010). However, these findings shed some light on the current trend, which causes an unpopular child now more likely due to children who were crying, sulking, cowardly, and shy. This means that a child is not preferred as a friend sociodramatic play not as disruptive but because of personality traits. There is an unpopular child will often feel left out of a feeling of selfdestructive feelings acknowledged, experiencing feelings of sadness, boredom and isolation. For children that school is a place that is fun and does not give security (Brendgen, Little \& Krappmann 2000) and finally they often truant or drop out of school (Kupersmidt 1983).

\section{CONCLUSIONS}

Based on the findings, we can conclude that girls are more popular than boys. While an unpopular children are applies to girls as well as boys. In addition, children are more dominant like a friend of the same gender while sociodramatic playing compared with the opposite sex friend. However, the relationship between children of different sexes does not describe a relationship of mutuality. While factor personality traits are more dominant factors that cause an unpopular child among his friends while sociodramatic playing of the feelings and behavioral factors. Therefore it is important and necessary for adults and professionals such as parents, teachers 
and counselors implement efforts to establish effective interaction between children and their peers do not face many problems of social adjustment and emotional, failure in education and drop out from school.

Further, the provision of a conducive learning center sociodramatic and planning learning and teaching that can attract children should focus on sensitizing teachers to the social development of children. It is important to ensure that all children have equal opportunities during sociodramatic play, whether girls or boys.

The implications of this study suggest the need to focus on teaching and learning to the next, social development should be taken into account that peer interaction associated with popular and unpopular students. It aims to control the occurrence of differences between the students and also the occurrence of a one-way relationship. Further studies should be conducted in-depth over time to identify the problems of social development of preschool children in relationships with peers so that service quality can be improved preschool education center.

\section{REFERENCES}

Asher, S.R., \& Hymel, S. (1981). Children's social competence in peer relations: Sociometric and behavioral assessment. In J.D. Wine \& M.D. Smye (eds.), "Social Competence”. New York: Guilford.

Barker, R. G., and Wright, H. F. (1955). Midwest and Its Children, Harper \& Row, New York.

Bergen, D. Ed. (1988). "Play as a Medium for Learning and Development”. Portsmouth, NH: Heinemann.

Bluiett, T.E. (2009). Sociodramatic play and the potentials of early language development of preschool children. Doctor of Philosophy Dissertation (The department of curriculum and instruction), The University of Alabama, Tuscaloosa, Alabama.

Boyle, B. \& Charles, M. (2010). Using sociodramatic play to support a beginning writer: 'Daniel, the doctor and the bleeding ball'. "International Journal of Early Years Education". 18(3): 213-225.

Brendgen, M., Little, T.D \& Krappmann, L. (2000). Rejected children and their friends: A shared evaluation of friendship quality? "MerrillPalmer Quarterly”. 46(1): 45-70.

Coolahan, K., Fantuzzo, J., Mendez, J. \& McDermott, P. (2000). Preschool peer interaction and readiness to learn: Relationships between classroom peer play and learning behavior and conduct. "Journal of Education Psychology”. 92(3): 458-465.

Deunk, M., Berenst, J. \& De Gloppers, K. (2008). The development of early sociodramatic play. "Discourse Studies". 10(5): 615-633.

Fabes, R.A., Shepard, S.A., Guthrie, I.K., Martin, C.L. (1997). Roles of temperamental arousal and gender-segregated play in young children's social adjustment. "Development Psychology". 33(4): 693-702.

French, D.C. (1990). Heterogeneity of peer-rejected girls. "Child Development". 61: 2028-2031.

Garvey, C. (1990). Play. Cambrige, MA: Harvard University Press.

Godwin. S. \& Ashiabi. (2007). Play in the preschool classroom: Its sociodramatic significance and the teacher's role in play. "Early Childhood Education Journal”. 35(2): 199-207.

Hallinan, M.T. (1981). Recent advances in sociometry. In S.R Asher \& J.M. Gottman (eds.), "The Development of Children's Friendships".New York: Cambridge University Press.

Hanline, M.F., Milton, S. \& Phelps, P. (2008). A longitudinal study exploring the relationship of representational level of three aspects of preschool sociodramatic play and early academic skills. "Journal of Research in Childhood Education”. 23(1): 19-28.

Hartup, W.W. (1992). Having friends, making friends, and keeping friends: Relationships as educational contexts. ERIC Digest, ED345854. http://ceep.crc.uiuc.edu/pubs/ivpaguide/appendi x/hartup-friends.pdf .[28 November 2010].

Ishak, Salma. (2001). "Play and friendship network: Towards young children's well-being”. Kertas kerja PSIMA National Conference Psychology. Anjuran Universiti Islam Antarabangsa Malaysia. Kuala Lumpur, 12-14 Julai.

Ishak, Salma. (2010). Bermain dan hubungan rakan sebaya dalam perkembangan kanak-kanak. Dalam. Azlin Hilma Hillaluddin \& Zarina Mat Saad (pnyt). "Penilaian Psikososial Kanakkanak: Isu-isu Kebajikan dan Perkembangan.” Kedah: Universiti Utara Malaysia.

Kartono, Kartini. (1996). "Pengantar Metodologi Riset Sosial”. Bandung: Mandar Maju

Kupersmidt, J.B., Coie, J.D. \& Dodge, K.A. (1990). The role of poor peer relationships in the development of disorder. In S.R. Asher \& J.D. Coie (eds.), "Peer Rejection In Childhood". New York: Cambridge University Press. 
Ladd, G.W. (1983). Social networks of popular, average, and rejected children in school settings. "Merrill-Palmer Quarterly". 29: 283307.

Lee, S. (2007). Trimangles and kittens: Mathematics within socio-dramatic play in a New Zealand early childhood setting. "Mathematics:

Essential Research, Essential Practice”. 2: 875-878.

McClellan, D. E. \& Katz, L. G. (2001). Assessing young children's social competence. ERIC Digest,ED450953. http://www.ed.gov/databases. [28 November 2010]

Moller, L.C., Hyme, S. \& Rubin, K.H. (1992). Sex typing in play and popularity in middle childhood. "Sex Roles". 26(7/8): 331-353.

Nurkancana, Wayan. (1993). Pemahaman Individu. Surabaya: Usaha Nasional

Piaget, Jean. 1972. "Play, Dream and Imitation in Childhood”. London (C. Gattegno and F. M. Hodgson. Traslated): Routledge \& Kegan Paul.

Oden, S. (1987). The development of social competence in children. ERIC Digest, ED281610. http://www.ed.gov/databases. [28 November 2010].

Santrock, J. W. (1995). "Life-Span Development, Perkembangan Masa Hidup”. Jilid 1. Jakarta: Erlangga.

Smilansky, S. (1979). "The Effects of Sociadramatic Play on Disadvantaged Preschool Children." New York: Wiley.

Yusuf, Syamsu. (2007). "Psikologi Perkembangan Anak dan Remaja”. Bandung: Remaja Rosdakarya. 